\title{
Analysis of English language textbooks in the light of English as an International Language (EIL): A comparative study
}

Naji Meidani, Elham

Ferdowsi University of Mashhad, Iran (elhanaji@gmail.com)

Pishghadam, Reza $\measuredangle$

Ferdowsi University of Mashhad, Iran (pishghadam@um.ac.ir)

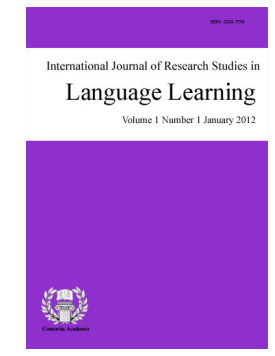

ISSN: 2243-7754 Online ISSN: 2243-7762

OPEN ACCESS

Received: 18 June 2012

Revised: 2 July 2012 DOI: $10.5861 /$ ijrsll.2012.163

Accepted: 1 August 2012

\section{Abstract}

The global spread of the English language has not only resulted in more non-native speakers than native speakers (Crystal, 1997), but it has even put into question the ownership of the language (Widdowson, 1994; Brumfit, 1995). Therefore, English is recognized as an international language that does not belong to any particular country and is used for global, political, cultural and financial exchange. The following study aimed to find out to what extent English language textbooks demonstrate the international status of the language by comparing four different textbooks published in different years. To this purpose, the following criteria were taken into account: references to Inner Circle countries, references to Outer and Expanding Circle countries, non-native accents, dialogues in non-English speaking countries, place of home culture and famous people. The analysis revealed differences among the selected books with a gradual tendency towards more recognition of the international status of English. Finally, the results were discussed and some suggestions were made in the context of English language learning and teaching.

Keywords: English as an International Language; textbook; analysis; culture; non-native 


\section{Analysis of English language textbooks in the light of English as an International Language (EIL): A comparative study}

\section{Introduction}

There is no denial that learning English has become an absolute necessity in today's globalized world. As the world's sole 'hypercentral language' (Cook, 2008), English has penetrated into all societies. "For better or worse, by choice or force, English has 'traveled' to many parts of the world and has been used to serve various purposes (Sharifian, 2009, p. 1). According to Chang (2006) English has been the prevailing foreign language in the curricula of educational institutions and in foreign language learning. English as an International Language (EIL) is a term used to characterize the status of English as the world's major second language and the commonest language used for international business, trade, travel, communication, and many others. Like the term World Englishes, the notion of International language recognizes that different norms exist for the use of English around the world (Richards \& Schmidt, 2002).

The global status of English has resulted in a huge textbook publication industry. A successful ELT course-book can sell over a hundred thousand copies a year (Littlejohn, 1992). Textbooks play a pivotal role in the realm of language teaching and learning and they are looked upon as an indispensable vehicle for foreign language learning. As noted by Cotazzi and Jin (1999), textbooks serve many roles in an EFL classroom, namely teacher, map, resource, trainer, authority, and ideology. Gray (2002) holds that ELT publishers present a vision of the world in the texts they produce and despite being designed explicitly for the teaching of the language; they are carriers of cultural messages. Studies have demonstrated gender bias, sexism and stereotyping (Porreca, 1984; Florent \& Walter, 1989; Clarke \& Clarke, 1999) in ELT textbooks.

It goes without saying that textbook analysis is not new to the field of ELT. Different criteria could be taken into account for analyzing ELT textbooks. To the researchers' best knowledge, however, no study has been done to conduct a comparative analysis of ELT textbooks based on the notion of EIL. Accordingly, the following study aims to analyze the developmental pattern of four popular ELT textbooks in terms of their adherence to the concept of EIL.

\section{Theoretical Framework}

The teaching of English to the speakers of other languages dates back to the late 15th century (Jenkins, 2000). From then on, English has been taught all around the world to people for whom it was not their mother tongue. Until recently, the goal of teaching English was to communicate effectively with native speakers, who were considered as the owners of the language. However, gradually, due to globalization, the view towards English changed. Jenkins (2000) summarizes the changes in the pattern of teaching English to the following: first of all, the dismantling of the British empire in ESL countries, particularly in the Indian subcontinent, which resulted in more active promotion of local, and L1-influenced varieties of English; secondly, the changes in the context of EFL, in which English has changed from a foreign language into an international one made it different from other foreign languages such as Spanish, Russian and Japanese; finally the switch from a purely intra-national use of English to an inter-national one.

In this line, Brumfit (1995) argues that "not only has English become international in the last half century, but scholarship about English has also become international: the ownership of an interest in English has become international" (p.16). In fact, this is the price English has to pay for becoming an international language (Widdowson, 1994). In fact, the argument goes even further as to deconstruct the terms 'native speaker' and 'non-native speaker' and replace them with 'monolingual English speaker' and 'bilingual English speaker' (Widdowson, 1994). With the recognition of the growing role of the language among non-native speakers from 
Analysis of English language textbooks in the light of EIL: A comparative study

different first-language backgrounds, some academics have been urging the teaching of English as a Lingua Franca (ELF), to remove it from the hands of its Anglo-Saxon native speakers, and to emphasize its role as a value-free means of international communication belonging equally to all who speak it as a first or second language (Sowden, 2011).

\subsection{Linguistic Imperialism and Globalization}

While there is no wonder that English is in demand everywhere, Phillipson (2009) expresses his concern about the promotion of the supply side by the British in order to ensure that the learning of English is to their benefit economically, culturally and politically. He calls this "linguistic imperialism" and relates it to "cultural imperialism". In language teaching, cultural imperialism includes the transmission of ideas about the culture of English-speaking countries occurring via textbooks, the choice of content etc. and entails the presentation of certain cultural stereotypes and values as universal and superior, while others as inferior either by omission or direct presentation (Richards \& Schmidt, 2002,). Phillipson (1992) believes that "ELT reconstitutes cultural inequalities between English and other languages" (p. 47). In the same vein, Brown (2007) warns about the danger of imposing a foreign value system on language learners and calls EIL (English as an International language) a "two-edged sword". The dominance of English has also resulted in the imposition of the Anglo-Saxon Judeo-Christian culture that goes with it so that indigenous cultures have been undervalued and marginalized" (Bisong, 1995). Smith (1981) also notes, "language and culture may be inextricably tied together but no one language is inextricably tied to any one culture and no one needs to become more like native speakers in order to use English well" (p. 10). Studies have shown the superior perception of English-speaking culture in different countries (Park, 2008; Isik, 2008).

Kachru (1986, as cited in Crystal, 1997) classified countries into three groups: The Inner Circle is formed by countries where English is the Native or major Language. The Outer Circle could be related to countries where English is the Second Language -ESL_, with a long history of institutionalized functions. Finally, the Expanding Circle; where English is studied as a Foreign Language (EFL). According to Phillipson (1992), the linguistic relation between the center and periphery has been and continues to be one of dominant and dominated languages.

The spread of the English language is said to have strong ties with globalization. In Bourdieu's (2001) view, the spread of English is one manifestation of this major phenomenon. As Sweeny (2006) argues, globalization acts as a force in the cultural hegemony that English has caused with the aid of a huge range of messages, icons, and brands. Pennycook (2007) asserts that among the languages, it is English which is closely tied to the process of globalization. Bottery (2000) holds that the development of globalization has been related to the authority of the English language. Short et al. (2001, as cited in Chang, 2006) indicated that cultural globalization was closely linked with the development of English as a global language. After the Second World War, US economy, technology and culture have made English part of the linguistic ecology of most nations (Mesthrie \& Bhatt, 2008).

\subsection{Presentation of Culture in ELT Textbooks}

Chastain (1988) relates "culture", a rather complex concept, to the teaching of a second language by dividing it into two groups: small c culture and large C culture. Small c culture concerns the way people live, while large $\mathrm{C}$ culture has to do with the economic, social, and political history and the great politicians, heroes, writers, and artists of a country.

Regarding the relationship between an international language and culture, Smith (1976; as cited in McKay, 2003) posited some assumptions: Learners of an international language do not need to internalize the cultural norms of the native speakers of that language, the ownership of an international language becomes denationalized and the educational goal of learning an international language is to enable learners to 
communicate their ideas and cultures to others. According to Modiano (2001), one way to come to terms with the cultural imposition of English language learning is to employ ELT practices which define English as an international language. He suggests a multiplicity of teaching practices in English classes in order to promote cultural equality and present a view of the language as belonging to a broad range of people and cultures.

Cortazzi and Jin (1999) differentiate between three types of ways which culture can be presented in language textbooks and materials: source culture, which uses the learners' own culture as content, target culture, which includes the culture of Inner Circle countries and international target culture, which draws on a variety of cultures from around the world.

McKay (2003), as well, holds that in the light of English as an international language, the cultural content of materials should not be limited to native English-speaking countries and should include local cultural content. Moreover, an appropriate method for ELT needs to be informed by local expectations regarding the role of the teacher and learner. McKay calls for the implementation of locally appropriate pedagogy and emphasizes the strength of bilingual teachers of English for their familiarity with the local culture. Therefore, local educators need to determine what linguistic information, cultural content, and teaching methodology are most appropriate for the local context so that learners will be able to use English to tell others about their own culture.

Cook (2008) states that successful L2 use is almost totally absent from textbooks. While most course books use England as a black cloth, they seldom present multilingual English people, even if multiculturalism is sometimes mentioned. Therefore, by the end of a language course, students will never have heard L2 users talking to native speakers let alone to other L2 users. L2 users fall into either category of tourist or visitor and have a lower power status. Crawford (1990) identified the negative effects of the textbooks. He asserted that textbooks (a) may distort the content because they often present an idealized, white and middle class view of the world and avoid the controversial issues; (b) since most of textbooks are written for global market, they may not reflect the specific needs of the learners in a particular setting; (c) they can deskill the teachers.

Many advantages have been recognized for the inclusion of local culture in ELT course books. Cummins (1994) states that choosing a familiar content facilitates the learning process, gives cognitive power to learners and brings in the positive contribution of Zone of Proximal Development (ZPD) as a gateway for identity formation and empowerment. Including international context, topics, and international varieties of English in ELT materials is a helpful step, but since they do not reflect the issues, culture, and realities of an EFL context (Canagarajah, 2006; Kumaravadivelu, 2006), high levels of mental and psychological involvement of learners cannot be realized. Dealing with familiar issues, context, and basically home culture, increases the personal attachment of both learners and teachers (Isik, 2008) by letting them "invest something personal in the learning process" (p. 140).

\subsection{Purpose of the Study}

The following study tries to find out the developmental pattern of the most popular English textbooks and analyze them in terms of the concept of EIL. Therefore, it addresses the following questions:

$>$ How do ELT textbooks differ in depicting Inner, Outer, and Expanding Circle countries?

$>$ How do ELT textbooks differ in recognizing dialogues in non-English speaking countries or dialogues with non-native accents?

$>$ How do ELT textbooks differ in treating learners' home culture?

$>$ How do ELT textbooks differ in depicting famous people? 


\section{Methodology}

\subsection{Textbook Selection}

Four books from four popular series of textbooks were selected. The textbook series covered a time span of about 12 years, based on their time of publication. The books are the following series: New American Streamline (Hartley \& Viney, 1994), Cambridge English for Schools (Littlejohn \& Hicks, 1996), Interchange Series Third Edition (Richards, Hull, \& Proctor, 2005), and Top Notch (Saslow \& Ascher, 2006). For the sake of homogenization, the books selected were all from the intermediate level of the four book series. They included: New American Streamline -Connections, Cambridge English for Schools (Students' Book Three), Interchange Third Edition (Students' Book 2), and Top Notch 3. Top Notch 3 is divided into two parts, i.e. A and B and they are in separate books. The aforementioned textbooks have been taught extensively in different countries around the world. In Iran, they are among the most used textbooks in English language institutes.

Among the four books, the Interchange Series and Top Notch claim to have a global perspective towards English. Interchange Third Edition asserts that the book reflects the fact that English is the major language of international communication and is not limited to any one country, region or culture. Top Notch also declares that it prepares students for interaction with both native and non-native speakers of English, both linguistically and culturally and that it treats English as an international language, rather than the language of a particular country or region. The other two books, however, have no such claims.

\subsection{Procedure}

In order to carry out the analysis, the following criteria were taken into account: references to Inner Circle countries, references to Outer and Expanding Circle countries, non-native accents, dialogues in non-English speaking countries, the place of home culture and famous people. For categorizing countries, the division made by Kachru (1986) was used. The number of dialogues in non-English speaking countries depicts that English is a lingua franca. Non-native accents convey one of the main principles of EIL, which is the acceptance of different varieties for speaking the language. The place of home culture was taken into account as one of the issues relating to the relationship between the local and the global. Finally, "famous people" was set as a criterion due to its symbolic value.

For calculating the references to Inner, Outer and Expanding Circle countries, five general cultural themes as put forward by Pfister and Borzelli (1977) were taken into account. The five categories include: social, personal, religion/arts/humanities, political systems and institutions and environmental concerns. The social category includes leisure, population/nationality, work, social class, and attitudes. For the personal aspect, eating/shopping, family relationships, and housing were taken into account. Religion/arts and humanities themes cover literature, music, arts, folklore, history and holy places. The political systems/institutions category includes government, education, law and justice. The environmental theme comprises geography, natural resources, weather, economic development and urban vs. rural. In order to conduct the analysis, the utilization of both visual and written modalities was assessed. The parts of each lesson were used as the unit of analysis. The lesson divisions varied in each textbook. Frequencies and percentages were calculated.

\section{Results}

\subsection{References to Inner Circle Countries}

Table 1 demonstrates the frequency of references to Inner Circle countries. The percentages are calculated out of the total number of references to all countries (Inner, Outer, and Expanding).As the results demonstrate, the frequency of representations of Inner Circle countries has decreased in this time span and their cultural 
Naji Meidani, E. \& Pishghadam, R.

themes have been reduced to mostly social matters.

Table 1

Frequency of references to Inner Circle countries

\begin{tabular}{|c|c|c|c|c|}
\hline Book & Country & Frequency & Percentage & Cultural themes \\
\hline \multirow{4}{*}{$\begin{array}{l}\text { New American } \\
\text { Streamline } \\
\text { (Connections) }\end{array}$} & USA & 56 & \multirow{4}{*}{92.06} & \multirow{4}{*}{$\begin{array}{l}\text { Social, personal, arts, political, } \\
\text { environmental }\end{array}$} \\
\hline & Britain & - & & \\
\hline & Canada & 2 & & \\
\hline & Australia & - & & \\
\hline \multirow{4}{*}{$\begin{array}{l}\text { Cambridge } \\
\text { English for } \\
\text { Schools (Book 3) }\end{array}$} & USA & 15 & \multirow{4}{*}{72.73} & \multirow{4}{*}{$\begin{array}{l}\text { Social, personal, arts, political } \\
\text { environmental }\end{array}$} \\
\hline & Britain & 10 & & \\
\hline & Canada & 5 & & \\
\hline & Australia & 7 & & \\
\hline \multirow{4}{*}{$\begin{array}{l}\text { Interchange Third } \\
\text { Edition (Book 2) }\end{array}$} & USA & 26 & \multirow{4}{*}{39.5} & \multirow{4}{*}{$\begin{array}{l}\text { Social, personal, arts, political } \\
\text { environmental }\end{array}$} \\
\hline & Britain & 2 & & \\
\hline & Canada & 2 & & \\
\hline & Australia & 2 & & \\
\hline \multirow{4}{*}{ Top Notch 3} & USA & 6 & \multirow{4}{*}{29.24} & \multirow{4}{*}{ Social } \\
\hline & Britain & 4 & & \\
\hline & Canada & 4 & & \\
\hline & Australia & 5 & & \\
\hline
\end{tabular}

In New America Streamline (Connections), 92.06\% of references to countries concern Inner Circle ones, and almost exclusively the United States. In Cambridge English for Schools, six units are devoted specifically to cultural matters, i.e. the making of Australia, the environment in Britain, Native Americans in the USA, USA: A melting pot, BBC and news Broadcasting, and Discover Canada. Evidently, the units only depict English speaking countries' cultural matters. They cover all the five categories of cultural themes by talking about their history, geography, social customs, people, and laws.

In Interchange, 39.5\% of cultural themes are concerned with Inner Circle countries. They include all three five aspects of the model taken into account. For example: American movies, Hollywood actors/actresses, American movie directors, American novels, history of New York (arts/humanities), American ski resorts (social), American presidents, Statue of Liberty (political), Official languages of Canada (social), American cities (environmental). In Top Notch 3, we see the least number of references to Inner Circle countries (29.24\%) and they include mostly social matters such as Thanksgiving and Mardi Gras.

\subsection{References to Outer and Expanding Circle Countries}

As the above Table shows, frequency of reference to Outer and Expanding Circle countries has increased. Older books depict less of these countries. The percentages have increased from $7.94 \%$ in New American Streamline (Connections) to $70.76 \%$ in Top Notch 3.Among the countries presented; Japan has the highest number of references in both Interchange 2 and Top Notch 3. New American Streamline (Connections) only presents Latin American nations. The variety of countries presented increases as we go further along. In Interchange 2, more East Asian countries are exhibited. Finally, in Top Notch 3, there is a wide selection of countries, covering all continents and regions.

Interestingly, the cultural themes taken into account also become more diverse. They include personal, social, arts, humanities, religion, political, and environmental matters. Here are some examples:

$>$ Religion: Ramadan, the month of fasting

$>$ Social: Chinese New Year 
Analysis of English language textbooks in the light of EIL: A comparative study

$>\quad$ Music: Mariachi band in Mexico

$>\quad$ Environmental: Bam earthquake in Iran

$>$ Political: the Education Ministry in Japan

$>$ Personal: dress and clothing in United Arab Emirates, Nepal, Taiwan, and many others

Table 2

Frequency of references to Outer and Expanding Circle countries

\begin{tabular}{|c|c|c|c|c|}
\hline Book & Country and Frequency & Overall Frequency & Percentage & Cultural themes \\
\hline $\begin{array}{l}\text { New American } \\
\text { Streamline } \\
\text { (Connections) }\end{array}$ & $\begin{array}{l}\text { Jamaica (1) } \\
\text { Venezuela (2) } \\
\text { Puerto Rico (1) } \\
\text { Dominican Republic (1) }\end{array}$ & 5 & 7.94 & environmental \\
\hline $\begin{array}{l}\text { Cambridge English for } \\
\text { Schools (Book 3) }\end{array}$ & $\begin{array}{l}\text { Brazil (2) } \\
\text { Argentina (2) } \\
\text { Bolivia (1) } \\
\text { Peru (2) } \\
\text { Venezuela (1) } \\
\text { Panama (1) } \\
\text { China (1) } \\
\text { Mexico (1) } \\
\text { Egypt (1) } \\
\text { India(1) } \\
\text { Spain (1) } \\
\text { Malta (1) }\end{array}$ & 15 & 27.27 & environmental \\
\hline $\begin{array}{l}\text { Interchange Third } \\
\text { Edition (Book 2) }\end{array}$ & $\begin{array}{l}\text { Argentina (2) } \\
\text { Brazil (3) } \\
\text { China (4) } \\
\text { Egypt (3) } \\
\text { Columbia (2) } \\
\text { Chez Republic(1) } \\
\text { India (4) } \\
\text { Japan (6) } \\
\text { Korea (5) } \\
\text { Mexico (4) } \\
\text { Paraguay (1) } \\
\text { Ecuador (1) } \\
\text { Singapore (2) } \\
\text { Taiwan (1) } \\
\text { France (2) } \\
\text { Italy (2) } \\
\text { Vietnam (2) } \\
\text { Peru (1) } \\
\text { Chile (1) } \\
\text { Germany (1) } \\
\text { Malaysia (1) }\end{array}$ & 49 & 60.5 & $\begin{array}{l} \\
\\
\\
\text { social } \\
\text { arts } \\
\text { humanities } \\
\text { political } \\
\text { environmental }\end{array}$ \\
\hline Top Notch 3 & $\begin{array}{l}\text { Brazil (4) } \\
\text { Mexico (2) } \\
\text { Japan (5) } \\
\text { Germany (2) } \\
\text { France (1) } \\
\text { Korea (2) } \\
\text { China (2) } \\
\text { India (4) } \\
\text { Chile (2) } \\
\text { Romania (1) } \\
\text { Saudi Arabia (1) } \\
\text { United Arab Emirates (1) } \\
\text { Egypt (2) } \\
\text { Iran (1) } \\
\text { Indonesia (1) } \\
\text { Hong Kong (3) } \\
\text { Italy (3) } \\
\text { Mongolia (1) } \\
\text { Thailand (3) } \\
\text { Taiwan (2) } \\
\text { Venezuela (2) } \\
\text { Zambia (1) }\end{array}$ & 46 & 70.76 & $\begin{array}{l}\text { social } \\
\text { arts } \\
\text { humanities } \\
\text { religion } \\
\text { political } \\
\text { environmental }\end{array}$ \\
\hline
\end{tabular}


In Interchange 2, 60.5\% of the references to countries include the Periphery. Examples of the cultural themes presented are the following:

$>\quad$ Personal: food and eating, e.g. Bulgogi from Korea, Feijoda from Brazil, fish head curry from Singapore

$>$ Social: famous celebrations, e.g. Brazilian Carnival, Chusok in Korea, New Years' Eve in Argentina, St. Anthony's Day in Mexico, Indian/Japanese/Korean wedding customs

$>$ Political: transportation system in Singapore

In order to find out what aspects of the Outer and Expanding circle countries are presented, in-depth content analysis was done on two reading passages found in Top Notch 3 (See Appendix). The content analysis of a reading passage on cultural change in Japan depicts the change of Japanese culture for the better, one that mirrors other changes in Japanese society. The passage, which is about the avoidance of honorifics in Japanese culture in recent years, implicitly gives a homogenizing view of the effects of globalization. Here are the adjectives used in the passage to talk about Japanese culture before:

\section{Traditional Old-fashioned Cumbersome Fallen out of use}

As we can see, the adjectives are either negative or have a negative connotation. On the other hand, Japanese culture now is presented in a positive way:

$\begin{array}{lll}\text { Open } & \text { Competitive } & \text { Exchanging ideas more freely } \\ \text { Making decisions more easily } & \text { Easier to talk } & \text { Equality-minded }\end{array}$

Hope for improvement

An interesting point is that the change is described as top-down: "Japanese workers get word from on high" as the title says. Thus, it disseminates the idea that Expanding circle countries are changing themselves to become akin to the homogenized view of globalization. Acar (2004) asserts, there exist many different conceptions of globalization and its influence on native cultures. One of the most frequently used terms for globalization is westernization or more specifically Americanization since western countries or the United States is now the superpower, with a leading economic, cultural and military position in the global order and also with many of the most apparently cultural expressions of globalization (Giddens, 2000).

The passage on Gandhi focuses on the aftermath of the independence of India from Britain. The passage implies that all the problems started after India gained independence from Britain. It does not mention anything about the great role Gandhi played in gaining independence from British domination. Instead, it only focuses on the fight between Muslims and Hindus, the fasting of Gandhi and his assassination by one of his own people. Overall, the passage undermines the accomplishments and contributions of Gandhi.

\subsection{Non-native Accents}

Table 3

Percentage of non-native accents

\begin{tabular}{lccc}
\hline \multicolumn{1}{c}{ Items } & Number of Speakers & Number of Speakers & Percentage \\
\hline New American Streamline (Connections) & 80 & 0 & 0 \\
Cambridge English for Schools (Book 3) & 32 & 0 & 0 \\
Interchange 2 & 32 & 2 & 6.25 \\
Top Notch 3 & 52 & 18 & 17.48 \\
\hline
\end{tabular}


Analysis of English language textbooks in the light of EIL: A comparative study

Table 3 demonstrates the frequency and percentage of times non-native accents can be heard in the listening parts of the books. Since the listening parts include both monologues and dialogues, the number of speakers was taken into account. With $17.48 \%$, Top Notch 3 covers the highest number of non-native accents. They include accents from Asian, Latin American, European and Middle-Eastern countries. Therefore, there is a considerable change compared to previous books which only depict American/British/Canadian and Australian accents.

\subsection{Dialogues in Non-English Speaking Countries}

\section{Table 4}

Percentage of dialogues in Non-English speaking countries

\begin{tabular}{lccc}
\hline \multicolumn{1}{c}{ Books } & Number of Dialogues & Number of Dialogues & Percentage \\
\hline New American Streamline & 80 & 0 & 0 \\
Cambridge English for Schools & 32 & 0 & 0 \\
Interchange 2 & 32 & 0 & 0 \\
Top Notch 3 & 20 & 5 & 25 \\
\hline
\end{tabular}

While one of the main principles of EIL is that English is used in Non-English speaking settings and between non-native speakers, we do not see much of that in textbooks. The only book which features dialogues between non-native speakers is Top Notch 3, making up $25 \%$ of all the dialogues. Students are supposed to listen to conversation staking place in a business meeting in Thailand between two non-native speakers. Two short conversation staking part in Russia between non-native speakers with non-native accents are presented, one at a hotel reception and the other at a dentist's office. Another dialogue happens in Costa Rica between two people, one from Italy and the other from Hong Kong. These settings show that English is used in Non-English speaking countries for the purpose of communication. In another instance, a group of people with different nationalities talk in a radio show with each other about the customs of their countries. All of them speak with a marking L1 accent and this is shown as something normal and natural. Thus, the international status of the language is acknowledged, by displaying it as a means for international communication and presenting one's own culture.

\subsection{Place of Home Culture}

In New American Streamline (Connections), there is no mention of learners' home culture. In fact, learners are bombarded with American stories, news, characters etc. Cambridge English for Schools (Book 3) goes a step further. The presence of learners' home culture is recognized. Nonetheless, learners are supposed to compare their native country with Inner Circle countries. For example:

$>\quad$ Your country and the United States: "How many people from your country gone to live in the United States? Where did they come from? Where did they go?" (Cambridge English for Schools 3, p. 83)

$>\quad$ Your country and Australia: "What contact does your country have with Australia? How is Australia different from your country?" (Cambridge English for Schools 3, p. 23)

The trend changes in the other two books. In every lesson, students are asked about their own country or place of living, without any reference to Inner Circle countries. The questions change in this way:

$>\quad$ "What questions could a visitor ask about your city?”(Interchange 2, p.10).

$>\quad$ "What ethnic foods are popular in your country?" (Interchange 2, p.22).

$>\quad$ "Imagine someone is going to visit your town, city, or country. Write a letter giving some suggestions for sightseeing activities" (Interchange 2, p. 34).

The same trend can be seen in Top Notch 3. However, since Top Notch covers a wider range of cultures and nationalities, the information regarding some countries are presented directly in the book. 
Naji Meidani, E. \& Pishghadam, R.

4.6 Famous People

Table 5

Famous figures presented in the books

\begin{tabular}{|c|c|c|c|}
\hline $\begin{array}{c}\text { New American } \\
\text { Streamline (Connections) }\end{array}$ & $\begin{array}{c}\text { Cambridge English for } \\
\text { Schools } 3\end{array}$ & Interchange 2 & Top Notch 3 \\
\hline $\begin{array}{l}\text { Sierra Kennedy } \\
\text { (American Olympic gold } \\
\text { medalist) }\end{array}$ & $\begin{array}{l}\text { John Franklin (English } \\
\text { sailorman) }\end{array}$ & $\begin{array}{l}\text { Nicole Kidman } \\
\text { (Hollywood actress) }\end{array}$ & $\begin{array}{l}\text { Mahatma Gandhi (Indian } \\
\text { humanitarian) }\end{array}$ \\
\hline $\begin{array}{l}\text { Jack Lumber (Canadian } \\
\text { Olympic gold medalist) }\end{array}$ & $\begin{array}{l}\text { The Beatles (American } \\
\text { Rock Band) }\end{array}$ & $\begin{array}{l}\text { Elvis Presley (American } \\
\text { superstar) }\end{array}$ & $\begin{array}{l}\text { Albert Schweitzer, } \\
\text { German doctor, } \\
\text { humanitarian) }\end{array}$ \\
\hline $\begin{array}{l}\text { Olga Ivanov (Russian } \\
\text { Olympic gold medalist) }\end{array}$ & $\begin{array}{l}\text { Christopher Columbus } \\
\text { (European explorer) }\end{array}$ & $\begin{array}{l}\text { Michael Jordan } \\
\text { (American basketball } \\
\text { player) }\end{array}$ & $\begin{array}{l}\text { Simon Bolivar (Latin } \\
\text { American liberator }\end{array}$ \\
\hline $\begin{array}{l}\text { Elvis Presley (American } \\
\text { Superstar) }\end{array}$ & & $\begin{array}{l}\text { Madonna (American } \\
\text { superstar) } \\
\text { Bill Gates (American, } \\
\text { world's wealthiest man) } \\
\text { Hale Berry (Hollywood } \\
\text { actress) } \\
\text { Johnny Depp } \\
\text { (Hollywood actor) } \\
\text { J.K. Rowling (British } \\
\text { author) } \\
\text { Kate Winslet } \\
\text { (Hollywood actress) } \\
\text { Tom Hanks (Hollywood } \\
\text { actor) } \\
\text { Brad Pitt (Hollywood } \\
\text { actor) }\end{array}$ & \\
\hline
\end{tabular}

Among the four books, Interchange 2 depicts the most number of celebrities. Except for Top Notch 3, the majority of the presented celebrities are from Inner Circle countries. New American Streamline (Connections) devotes a whole unit to the life of Elvis Presly. In Interchange2 learners are supposed to listen to a recipe for Elvis Presly's favorite peanut butter and banana sandwich. Cambridge English for Schools (Book 3) only features the well-known figures related to Inner Circle countries. A major part of a unit is about the Beatles, their history and their evolution. In Top Notch 3, however, we see the inclusion of international figures from Outer and Expanding Circle countries, such as Mahatma Gandhi, Albert Schweitzer and Simon Bolivar. The types of figures change from actors, singers and sportspeople to characters with humanitarian activities and contributions.

\section{Discussion}

The general goal put forward by this study was to analyze ELT textbooks in terms of their adherence to the concept of EIL. To this purpose, four textbooks with four different publication dates were analyzed and compared based on their references to Inner, Outer and Expanding Circle countries, recognition of dialogues in non-English speaking countries, non-native accents, place of learners' home culture and the types of famous people presented.

With respect to the first question, the textbook analysis revealed a tendency towards multiculturalism throughout the selected period. The presentation of cultural themes of Outer and Expanding Circle countries has become more numerous and more diverse; while that of Inner Circle countries has decreased and become less highlighted. Acknowledgement of other cultures demonstrates that overall textbooks are moving more towards the principles of EIL. However, there is still room for inclusion of marginalized cultures. More importantly, the aspects of the Expanding and Outer Circle countries being depicted need to be taken into account. As the content 
Analysis of English language textbooks in the light of EIL: A comparative study

analysis in this study revealed, there may be biases in what is presented from these cultures.

Regarding the second question, a great difference was found among the books in terms of non-native accents and dialogues in non-English speaking countries. According to Jenkins (2000), in order to democratize the English language, pronunciation is the area of greatest prejudice and preconception and the most resistant to change. Therefore, if English is to achieve true integrity as an international language, it must acknowledge an international phonology. While the first two books contained absolutely no non-native accent, Interchange 2 and Top Notch 3 had a percentage of dialogues with L1 accents. This was more conspicuous in Top Notch 3 . These listening activities convey the message that not only speaking with an L1 accent is not derogatory, but also we should learn to understand people speaking English with an L1 accent. Among the four books, only Top Notch 3 featured dialogues in non-English speaking countries. These "lingua franca contexts" (Jenkins, 2000), give a more realistic view of the way English is used in today's world. In these settings, people "bilingual English speakers" (Widdowson, 1994) use the language to communicate with each other as tourists, visitors or businesspeople in Outer and Expanding Circle countries. This is in sharp contrast with Cook's (2008) evaluation of some English language textbooks in which L2 users were mostly shown as tourists or visitors who ignorantly asked the way or desperately bought things in English speaking countries. The stance taken by Top Notch 3 is certainly in line with the international status of the language. However, there is still a long way to go to present a completely democratized view of these issues.

Concerning the third question, there was a gradual change in the way learners' home culture was acknowledged. In New American Streamline (Connections) no reference is made to the learners' own countries whatsoever. The interesting change found in Cambridge English for Schools (Book 3) was that learners have to compare their own country with Inner Circle countries. This way, Inner Circle countries are presented as the norm, demonstrating the dominant relationship between the Center and the Periphery (Phillipson, 1992). In Interchange 2 and Top Notch 3, learners are supposed to think about their own lives, experiences, culture or customs in each lesson based on the topic presented. Of course, one does not expect the presence of all cultures in a global course-book, since it adheres to a "one-size fits all" policy. Therefore, activities which require the learner to think about his/her own environment are noteworthy. This attempt to link the global with the local is in line with the view that the local is always imbricated in the global or what is called "glocalization" (Robertson, 1995). Nevertheless, the direct inclusion of the local in terms of characters, place, names and references may have different effects.

As for the depiction of well-known figures, the analysis reveals the inclusion of mostly Inner Circle country figures, except for Top Notch 3. As cultural icons, Hollywood superstars mostly demonstrate the values of the American way of living. By presenting Hollywood figures and wealthy people as success stories, certain values are implied as universal. Consumerism and materialism are glorified by the depiction of these characters. This is reminiscent of the cultural imperialism that Phillipson $(1992,2009)$ warns about. In this line, teaching English affects people's thinking modes and value judgments, while there seems to be no relevance of these points to learning the language. Using Bourdieu's (2001) term, American superstars exhibit "symbolic capital". Cook's (2008) textbook analysis also revealed presentation of monolingual celebrities which had no relevance to whether any of them use second languages successfully. These results demonstrate the hidden social, political and economic agenda backing the current status of the language (Phillipson, 1992, 2009).

\section{Conclusion}

As already mentioned, in this study we tried to examine contents of some generations of ELT textbooks. Overall, the outcomes of this study revealed that the recent textbooks written for English language learning adhere more to the principles of EIL. In fact, these textbooks generally try to depict more aspects of the Expanding and Outer Circle countries.

This study has a number of implications. First of all, it might provide food for thought for materials 
designers and perhaps encourage them to create local materials and thus lead to scientific and systematic localization movements. Second, teacher trainers might use the results of the study to make the prospective teachers adopt more critical stance towards textbooks. Third, this study can act as an eye-opener for teachers who are currently involved in the process of English language learning and teaching, making them more conscious and critical of what goes on in the materials they teach.

Based on the results of the study, the following suggestions are made. First, more in-depth analysis needs to be done on ELT textbooks from different perspectives, i.e. social, political, economic, etc. to clarify what exactly they are propagating. Second, further analysis of books help teachers and learners to gain deep and critical understanding of the material presented in English textbooks that are developed in English-speaking countries and taken for granted as the best sources for language learning. Finally, think-aloud procedures can be done to investigate the attitudes of the learners towards the cultural content presented in the textbooks.

\section{References:}

Acar, K. (2004). Globalization and language: English in Turkey. Sosyal B L Mler, 2(1), 1-10. Bisong. (1995). Language choice and cultural imperialism. ELT Journal, 49(2), 22-132.

Block, D., \& Cameron, D. (2002). Globalization and language teaching. London and NY: Routledge.

Bottery, M. (2000). Education, policy and ethics. London: Continuum.

Bourdieu, P. (2001). Conter-feux 2. Pour un mouvement social Europeen. Paris: Raison d'agir.

Brown, H. D. (2007). Principles of language learning and teaching (5th ed.). White Plains, NY: Pearson Education.

Brumfit, C. J. (1995). The role of English in a changing Europe: where do we go from here? Best of ELTECS. The British Council.

Canagarajah, A. S. (2006). TESOL at forty: What are the issues? TESOL Quarterly, 40(1), 9-34. $<$ http://dx.doi.org/10.2307/40264509>

Chang, J. (2006). Globalization and English in Chinese higher education. World Englishes, 25(3), 513-525. $<$ http://dx.doi.org/10.1111/j.1467-971X.2006.00484.x $>$

Chastain, K. (1988). Developing second language skills: Theory and practice ( $3^{\text {rd }}$ ed.). USA: Harcourt Brace Jovanovich.

Clarke, J., \& Clarke, M. (1990). Stereotyping in TESOL materials. Modern English Publications.

Cook, V. (2008). Second language learning and language teaching (4th ed.). UK: Hodder Education.

Cotazzi, M., \& Jin, L. (1999). Cultural mirrors materials and methods in the EFL classroom. In E. Hinkel (Ed.). Culture in second language teaching and learning. Cambridge: CUP.

Crawford, J. (1990).How authentic is the language in our classrooms? Prospect, 6(1), 47- 54.

Crystal, D. (1997). English as a global language. Cambridge: CUP.

Cummins, J. (1994). Knowledge, power, and identity in teaching English as a second language. In F. Genesee (Ed.), Educating second language children (pp. 33- 58). Cambridge: CUP.

Florent, J., \& Walter, C. (1989). A better role for women in TEFL. ELT Journal,43(3), 45-78. $<\underline{\text { http://dx.doi.org/10.1093/elt/43.3.180> }}$

Giddens, A. (2000). Runaway world: How globalization is reshaping our lives. New York: Routledge.

Gray, J. (2002). The global coursebook in ELT. In D. Block \& D. Cameron (Eds.), Globalization and language teaching (pp. 151-167). New York: Routledge.

Hartley, B., \& Viney, P. (1994). New American streamline: Connections. Oxford: OUP.

Isik, A. (2008). Linguistic imperialism and foreign language teaching. The Journal of Asia TEFL, 5(1), 123-144.

Jenkins, J. (2000). The phonology of English as an international language. Oxford: OUP.

Kachru, B. B. (1986). The alchemy of English: The spread functions and models of non-native Englishes. Oxford: Pergamon.

Kumaravadivelu, B. (2006). Understanding language teaching: From method to postmethod. Mahwah, New Jersey: Lawrence Erlbraum Associates. 
Analysis of English language textbooks in the light of EIL: A comparative study

Littlejohn, A. (1992). Why are ELT materials the way they are? Unpublished doctoral dissertation, Lancaster University.

Littlejohn, A., \& Hicks, D. (1996). Cambridge English for schools: Students' book three. Cambridge: CUP.

McKay, S. (2003). Teaching English as an international language: The Chilean context. ELT Journal, 57(2),

139-148. <http://dx.doi.org/10.1093/elt/57.2.139>

McKay, S. (2003). Toward an appropriate EIL pedagogy: Reexamining common ELT assumptions. International Journal of Applied Linguistics, 13(1), 1-22. <http://dx.doi.org/10.1111/1473-4192.00035>

Mesthrie, R., \& Bhatt, R.M. (2008). World Englishes: The study of new linguistic varieties. Cambridge: CUP.

Modiano, M. (2001). Linguistic imperialism, cultural integrity and EIL. ELT Journal, 55(4), 339-346. $<$ http://dx.doi.org/10.1093/elt/55.4.339>

Park, H. (2008). Linguistic imperialism and the English-learning boom in Korea: A case analysis of weekend Korean schools in the U.S. The Review of Korean Studies, 11(2), 117-137.

Pennycook, A. (2007). Global Englishes and transcultural flows. NY and London: Routledge.

Phillipson, R. (1992). Linguistic imperialism. Oxford: OUP.

Phillipson, R. (2009). Linguistic imperialism continued. NY and London: Routledge.

Pifster, G. C., \& Borzelli, P. (1977). Surface cultural concepts: A design for the evaluation of cultural materials in textbooks. Unterrichtspraxis, 10, 102-108. <http://dx.doi.org/10.2307/3529798>

Pishghadam, R., \& Attaran, A. (in press). Rhetorical patterns of argumentation in EFL journals of Persian and English. International Journal of Research Studies in Language Learning.

Porecca, K. (1984). Sexism in current ESL textbooks. TESOL Quarterly, 18(4), 23-43.

Richards, J. C., \& Schmidt, R. (2002). Dictionary of language teaching and applied linguistics (3rd ed.). UK: Pearson Education.

Richards, J. C., Hull, J., \& Proctor, S. (1998). Interchange series: Students' book 2 (3rd ed.). Cambridge: CUP.

Robertson, R. (1995). Glocalization: time-space and homogeneity-heterogenity. In M. Featherstone, S. Lash, and R. Robertson (Eds.), Global modernities (pp. 25-44). London: Sage Publications. <http://dx.doi.org/10.4135/9781446250563.n2>

Saslow, J., \& Ascher, A. (2006). Top notch: 3A. USA: Pearson-Longman.

Sharifian, F. (2009). English as an international language: Perspective and pedagogical issues. Clevendon: Multilingual Matters.

Short, J. R., Boniche, A., Kim, Y., \& Li, P. L. (2001). Cultural globalisation, global English, and geography journals. Professional Geographer, 53(1), 1-11. <http://dx.doi.org/10.1111/0033-0124.00265>

Smith, L. (1976). English as an international auxiliary language. RELC Journal, 7(2), 38-43. $<$ http://dx.doi.org/10.1177/003368827600700205>

Smith, L. E. (Ed.). (1981). English for cross-cultural communication. London: Macmillan.

Sowden, C. (2011). ELF on a mushroom: the overnight growth in English as a Lingua Franca. ELT Journal,

Sweeny, S. (2006). The culture of international English. Retrieved from http://www.etprofessional.com/content/view/806/5

Widdowson, H. G. (1994). The ownership of English. TESOL Quarterly, 28(2), 377-389. $<$ http://dx.doi.org/10.2307/3587438> 


\section{Japanese Workers Get Word from on High: Drop Formality}

By Norimitsu Onishi

HIROSHIMA, Japan, Oct. 30, 2003. The change in policy came directly from the Tokyo headquarters of Elpida Memory, a semiconductor maker. Elpida's 1,366 workers were told to stop addressing each other by their titles and simply to add the suffix -san to their names. Many Japanese have dropped the use of titles to create a more open - and they hope, competitive - culture. This change mirrors other changes in Japanese society, experts say. Equality minded parents no longer emphasize honorific language to their children, and most schools no longer expect children to use honorific language to their teachers. What is clear is that the use of honorific language, called keigo, to elevate a person or humble oneself, has especially fallen out of use among young Japanese. Japanese, perhaps more than any other language, has long taken account of social standing. In Japanese, there are many ways to say I or you, calibrated by age, circumstance, gender, social position and other factors. Verb endings, adjectives and entire words also shift according to the situation. These days, companies hope the use of - san - less cumbersome than the longer titles traditionally used - will allow workers to exchange ideas more freely and make decisions more quickly. In 2001, 59 percent of companies with more than 3,000 employers had adopted such a policy, compared with 34 percent in 1995, according to the Institute of Labor Administration of Japan. "It's easier to talk now," said Kazuyoshi Iizuka, a 32-year-old employee at the Tokyo headquarters of Elpida. The factory's president, Takehiko Kubota, 59, who describes himself as "old-fashioned," sent an e-mail message on Sept. 5 explaining the policy to his staff.

Adapted from the New York Times, Oct. 30, 2003

\section{People Who Changed the World: Mohatma Gandhi}

Mohandas Karamachand Gandhi believed that the way people behave is more important than what they accomplish. Gandhi studied law but became known for social action. He practiced non-violence to help India achieve independence from Britain. In 1947, India was granted independence, but the country was broken into two states-India and Pakistan — and fighting between Hindus and Muslims began. But Gandhi believed in an India where Hindus and Muslims could live together in peace. On January 13, 1948, at the age of 78, Gandhi began a fast, not eating anything for days, with the purpose of stopping the war. After five days, the opposing leaders said they would stop the fighting and Gandhi broke his fast and started eating again. Sadly, twelve days later Gandhi was assassinated by a Hindu fanatic who strongly opposed his vision of an India for both Hindus and Muslims. The Indian people called Gandhi "Mahatma," meaning "Great Soul."

Adapted from http://www.lucidcafe.com 